\title{
A CONCEPTUAL FRAMEWORK FOR ANALYSING IMMIGRATION POLICY: A CASE STUDY OF RECENT DEVELOPMENTS IN GERMANY'S ASYLUM POLICY
}

\author{
Claudia SCHNEIDER
}

COBISS 1.01

\begin{abstract}
A Conceptual Framework for Analysing Admission Policy: A Case Study of

Recent Developments in Germany's Asylum Policy

Germany's asylum policy and the debate surrounding it underwent a significant shift in 2015 when asylum applications increased considerably over previous years. Rather than moving towards more restriction, as was the case in the past when asylum applications saw a substantial rise, the German government responded towards refugees in an open and welcoming manner. This article will analyse the developments which led to the German government's "we can manage it" response, using a conceptual framework which considers structural and agency concerns and the interconnection between the two. The framework centres on processes within the party political system and the way they were or were not influenced by developments and structures in the wider socio-political and economic environment and by politicians' perceptions, beliefs and goals. The findings show that a new alliance was formed between the conservative CDU party and the social democratic SPD party, reflecting a political debate on asylum seekers and refugees which combined an explicit humanitarianism within Germany with a hierarchical classification of migrants who were "more or less needy" of protection, limiting the explicit humanitarianism within Germany to specific groups of migrants and refugees. KEY WORDS: asylum seekers, far right, refugees, structure-agency, political debate
\end{abstract}

\section{IZVLEČEK}

Konceptualni okvir analize politik sprejema: študija primera trenutne usmeritve nemške azilne politike

Nemška azilna politika je leta 2015, ko se je v primerjavi s prejšnjimi leti občutno povečalo število prošenj za azil, doživela presenetljiv premik. $V$ nasprotju s pričakovanji nemška vlada ni zaostrila pogojev sprejema, kot je bilo to $\mathrm{v}$ navadi v preteklosti, temveč je beguncem izrazila dobrodošlico. Članek ponuja analizo dogodkov, ki so pripeljali do tovrstne vladne usmeritve, in pri tem uporabi konceptualni okvir, ki upošteva strukturo, delovanje in njun preplet. Osredotoča se na procese znotraj strankarskega političnega sistema in analizo morebitnega vpliva nanj s strani struktur v širšem družbenopolitičnem in ekonomskem okolju, ter percepcij, verovanj in ciljev politikov. Izsledki kažejo, da se je med konzervativno stranko CDU in socialnodemokratsko stranko SPD oblikovala nova zaveza. Obe sta zavzeli stališče, da so nekateri migranti zaščite bolj "potrebni« kot drugi. S hierarhizacijo sta domet humanitarizma v Nemčiji omejili na specifične skupine migrantov in beguncev. KLJUČNE BESEDE: prosilci za azil, radikalna politična desnica, begunci, struktura/delovanje, politična debata

$\mathrm{PhD}$, Principal Lecturer; Anglia Ruskin University, Faculty of Social Care and Education, East Road, CB1 1PT; claudia.schneider@anglia.ac.uk 


\section{INTRODUCTION}

2015 was a turning point in Germany's asylum policy and the related political debate on asylum. There was a significant increase in first applications for asylum (441,899 compared to 173,072 in 2014 ) of which 158,657 were filed by Syrians fleeing the civil war. ${ }^{1}$ To the surprise of many, Chancellor Merkel and large parts of the conservative CDU (Christian Democratic Union) responded in September 2015 with a welcoming and open border policy towards refugees, announcing a 'we can manage it' (wir schaffen es) attitude. They openly contradicted the Dublin Convention which demands that refugees apply for asylum in the first EU country which they enter. This welcoming position stands in contrast to the position of CDU politicians, who had warned about overloading and the risk to national stability in the context of refugees arriving from former Yugoslavia in the early 1990s, and through their position triggered a constitutional change regarding political asylum in 1993 which led to a more restrictive asylum policy (see Schneider 2006).

This article aims to analyse the responses by the German government to the refugee movements in 2015. It will start with the presentation of a framework for the analysis of admission policy (see Schneider 2006), followed by an application of the framework to the development of Germany's asylum policy in 2015. Theoretical approaches in immigration policy have often focused on either structural or agency components. This article places emphasis on explicitly analysing both structure and agency and how they interconnect in a specific case study of asylum policy. The framework was informed by studies which link agency and structure in a non-deterministic manner and in particular Freeman's (1979) earlier study of the subject. At the heart of the framework is the analysis of the link between structure and agency within the political party environment, followed by an analysis of the wider environment, politicians' justification schemes and the interconnection between politicians' agency and the wider environment (see Schneider 2006).

\section{AN OVERVIEW OF THE LITERATURE ON IMMIGRATION POLICY, WITH A SPECIFIC FOCUS ON FREEMAN (1979)}

Up to the early 1990s, studies on immigration policy typically focused on structural factors (economic and/or political) and were often embedded in a wider framework of a hypothesis-testing or deterministic approach (using downward reduction) (see, for example, Castles, Kosack 1973; Freeman 1995; Kay, Miles 1992). "Opposite" approaches, which view immigration policy as being determined by agency (upward reduction) have not been formulated explicitly. Although a number of authors, such as Layton-Henry (1992) and Rich (1986) have emphasised the role of politicians in specific case studies of immigration policy, they did not propose upward reduction. Since the mid-1990s, authors have increasingly acknowledged both structure and agency as independent items of analysis, although most have not developed an explicit discussion regarding the structure-agency link (e.g. Brochman 1999; Joly 1996; Joppke 1999). Only a few scholars, such as Richmond (1994) and

1 The top five countries of origin in 2015 were: Syria $(441,899)$, Albania $(53,805)$, Kosovo $(33,427)$, Afghanistan (31,382) and Iraq (29,784). 
Freeman (as early as 1979) have discussed the theoretical aspects of the structure-agency link more systematically in the context of immigration policy. The approaches can therefore be classified into three groups: firstly, those which view immigration policy as being determined by structural factors; secondly, approaches which look at actors and structures in less deterministic ways but do not explicitly discuss how they interrelate; and thirdly, those which include a more systematic discussion of the role of structures and agency in the context of immigration policy (see Schneider 2006). This article aims to present a framework which focuses more explicitly on the structure-agency link and is informed in particular by Freeman's (1979) earlier study, which considers agency and structures within a non-deterministic framework; interestingly it has not been applied by later authors analysing different scenarios of immigration policy.

In his comparative study of British and French immigration policies after the Second World War, Freeman (1979) offers a theoretical framework which explicitly acknowledges structure and agency and the link between them. At a time when approaches towards immigration policy were often based on structural explanations, he placed emphasis on politicians' justifications and beliefs. While emphasising politicians as an independent analytical category, Freeman does not ignore the structural context. He acknowledges both politicians' choices and the limiting/enhancing effect of the structural context upon these choices. Politicians' decision-making processes are analysed in the context of two layers: external constraints on policy (economic, demographic and historical conditions) and proximate determinants (party systems, political styles and belief systems of decision-makers) (Freeman 1979: 311). It is also important to note that Freeman did not start off to test a hypothesis, but began with a descriptive account and 'generated plausible hypotheses' after his investigation, formulating his analytical/theoretical framework of external constraints and proximate determinants during his investigation. This underscores the fact that Freeman's approach is, in methodological terms, a qualitative or theory-building approach. By arguing that structural influences on immigration policy need to be mediated via politicians' perceptions and belief systems, Freeman explicitly addresses the structure-agency link. ${ }^{2}$

\section{A CONCEPTUAL FRAMEWORK FOR ADMISSION POLICY}

The framework (see Figure 1) is informed by Freeman (1979), but distinguishes more explicitly between: 1) politicians' decision making processes (their values, goals and perceptions); 2) the wider environment (e.g. social, political, historical and legal structures and actions at a national and international level); and 3) the party political system (where the core processes take place with regard to decision-making on immigration policy and legislation) (see Figure 1; see also Schneider 2006, 2009). Structure is understood here as both macro factors (such as the economy, legislation and political structure) and normative and interactive structures which govern organisations, such as political parties. Agency refers to actions and psychological dimensions such as beliefs, perceptions and goals of individuals which contribute to the development, maintenance and changing of structures.

2 Interestingly, Freeman's $(1995,2006)$ later studies follow theory-testing approaches and are based on a variety of hypotheses relating to the political system. They have been referred to more often in immigration literature than his earlier study which offers a more flexible analytical framework. 
Fig 1: A conceptual framework for the study of immigration policy (adapted from Schneider 2006, 2009)
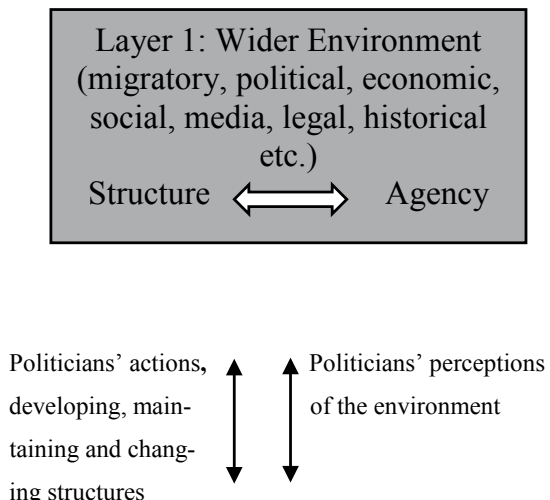

Layer 2: Political Party System

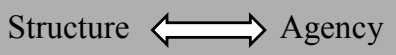

Layer 3: Politicians' Decision-Making (Agency)

Perceptions, normative principles and goals

The three layers in Figure 1 are interlinked: Layer 3 is linked with layer 1 and 2 by focusing on politicians' perceptions of the wider environment and the party political system. The perceptions together with individuals' goals and beliefs influence actions, which change or maintain structures relating to admission policy within the party political system. Below I will discuss the three (interrelated) layers in separate sections, before they are applied to Germany's refugee policy in 2015.

\section{Layer 1: The wider environment}

The wider environment acknowledges structural factors and processes which go beyond the party political system, such as the wider economic, political and media structures and migration itself. The structures are fluid and reflect an ongoing process of development, maintenance and change via agency. As the focus of the framework is on the party political system, the structure-agency link within the wider environment will not be analysed further, and instead the focus will be on the macro structures and processes such as migration itself, the economy and the socio-political context and politicians' perceptions of these structures. Admission policy literature acknowledges a range of wider structural factors, including economic factors (see the classic study by Castles, Kosack 1973 and more recently Cornelius, Rosenblum 2005) and political factors (e.g. Freeman 2006; Schain 2006). Since the early 1990s, factors relating to the nation state, such as conceptions of 
national identity and sovereignty, have also been prominent (Joppke 1999, 2005; Sassen 1996; Thouez, Channac 2006), and are often linked to discussions relating to legal systems, laws and rights (see Gibney 2004; Joppke 1999, 2008). A number of authors have looked at the role of governmental and non-governmental organisations and interest groups which are involved in decision-making processes (see Boswell 2009; Lahav, Guiraudon 2006; Statham, Geddes 2006; Zincone 2006). Other factors, such as historical ties (Geddes 2003) and the media (Boswell 2010; Lahav, Guiraudon 2006) have also been considered although often in connection with one or several of the factors outlined above.

Although an objective analysis of these wider structures or macro factors is relevant to understanding the context of immigration policy, they should not be correlated merely with developments regarding admission policy. Such a correlation between macro factors and developments regarding admission policy would overlook agency and ignore (in the specific framework presented here) the fact that politicians are the main mediators between the macro structures and developments regarding admission policy. Instead, the perceptions and interpretations of these wider structures by politicians need to be researched identifying how they have influenced actors' decision-making processes. Freeman's (1979) classic study of immigration policy in Britain and France highlights, for example, how politicians' different interpretations and perceptions of seemingly similar objective (economic) situations can lead to significantly different immigration policies.

\section{Layer 2: The narrower context of the political party system}

At the heart of the framework lies the party political system. The analysis here focuses on how actors within the system maintain or change (or, in Archer's 1995 words, elaborate) structures (e.g. interactive and normative structures). Classic studies which have looked more closely at political decision-making processes include those by Freeman (1979) and Layton-Henry (1992). More recently, Zincone (2006) compared the processes in the political party system relating to two migration laws in Italy passed in 1998 and 2002 by two different governments.

The analysis of the structure-agency link within the party political system will be informed by Archer's (1995) approach, which organises the link between agency and structure along temporal lines. Her so-called 'morphogenetic sequence' understands structure as the intended and unintended outcome of past actions that pre-dates and conditions present action. Present action is viewed as elaborating (i.e. either maintaining or changing) this structure (see Fig. 2). 
Fig. 2: Archer's (1995: 76) morphogenetic sequence (amended)

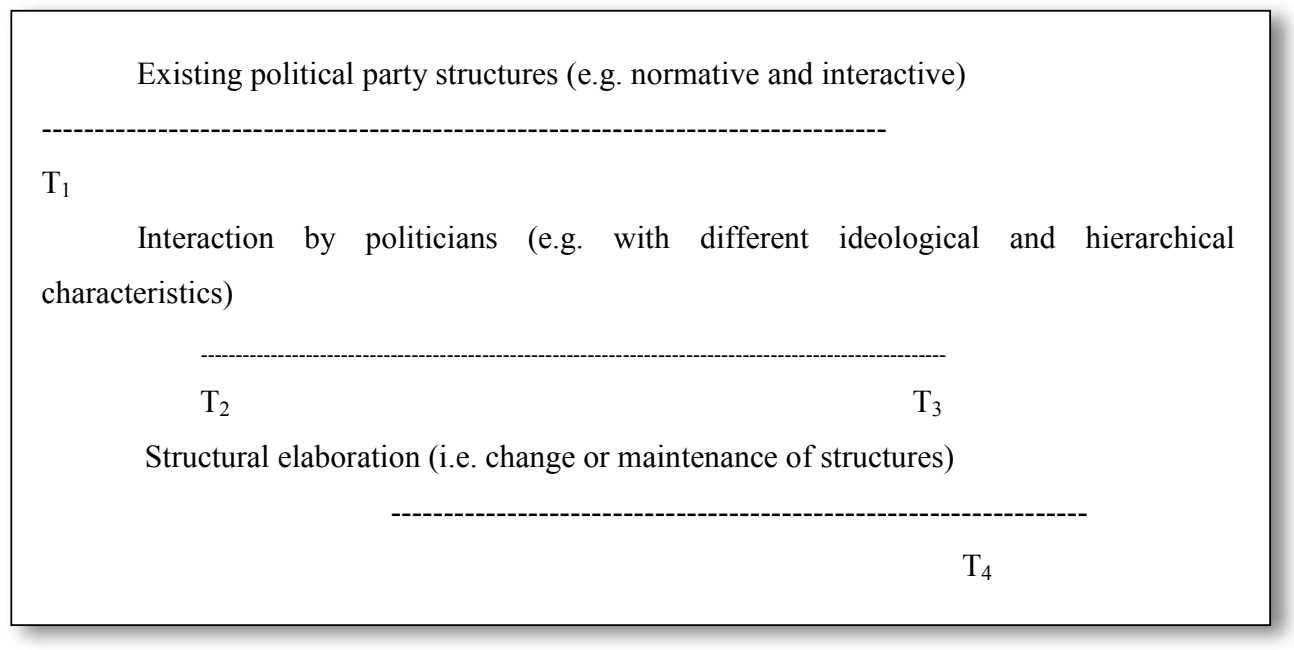

In the next section, Archer's model will be applied to processes within the party political system, researching how structures (e.g. interactive and normative) within the party political system existing at the beginning of 2015 (T1) were elaborated (i.e. maintained or changed) by politicians throughout the first eight months of 2015 (T2), leading to an elaboration of admission policies by autumn 2015 (T3). ${ }^{5}$

Layer 2 also focuses on the different characteristics of actors (i.e. politicians in our case) within the context of the political party system, such as their "hierarchical" and ideological positions, which affect the way structures relating to admission policy are elaborated. Münch (1992) and Perlmutter (1996) found, for example, that politicians of local municipalities in Germany and Italy respectively initiated changes resulting in more restrictive rules on immigration; this is also confirmed in a study on constitutional change in Germany (see Schneider 2006). As the framework presented in this article follows a theory-building approach, it is not proposed a priori that higher or lower-ranking politicians, or specific ideological positions, are more influential than others regarding the formation of admission policy. It merely highlights the potential relevance of politicians' hierarchical and ideological positions in understanding decision-making processes relating to admission policy. The case study of Germany's admission policy in 2015 actually reflects a scenario which differs from the standard ideas about the link between lower-level political structures and restrictive positions on migration policy, as discussed by Münch (1992) and Perlmutter (1996).

\section{Layer 3: The subjective level of politicians' decision-making}

Layer 3 explores the more subjective dimensions of decision-making and differentiates between actors' goals, their normative principles and their perceptions of the narrower and wider environment (Simon 1982; Sen 1982). Apart from ideological analyses, authors have focused less on politicians' decision-making processes at an individual level. Kelly and 
Trebilcock (1998: 448) argue that 'ideas and values have substantial independent explanatory power' to understand Canadian immigration policy. ${ }^{3}$ More recently, Boswell (2009) has also emphasised the role of expert knowledge in politicians' decision-making processes in the context of German and British immigration policy.

\section{A STUDY OF GERMANY'S RECENT REFUGEE ADMISSION POLICY}

This section will apply the above layers to the case study of German admission policy towards asylum seekers in 2015. The wider environment, the party political system and politicians' justification systems will be discussed separately, before linking them in a final discussion section.

\section{The wider environment}

The wider environment encompasses a broad range of areas, as outlined above. This article will focus in particular on the German and European situation regarding refugees and asylum seekers, public opinion, the economic situation and the socio-political climate in Germany.

Asylum applications (first applications) in Germany reached 441,899 in 2015, which was a significant increase over $2014(173,072)$. In 2008 there were only 22,085 applications, which by 2012 had increased to 64,539. The top five countries of origin in 2015 were: Syria $(158,657)$, Albania $(53,805)$, Kosovo $(33,427)$, Afghanistan $(31,382)$ and Iraq $(29,784)$ (Bundesamt für Migration und Flüchtlinge 2016). Germany has accepted larger numbers of Syrian refugees since 2013 when EU member countries agreed to take a contingent of Syrian refugees from Lebanon, which had received the largest influx of refugees; consequently, Germany accepted 15,000 Syrian refugees in 2013 under the EU agreement. ${ }^{4}$ By April 2014, 19,000 (non-contingent) refugees from Syria had arrived at Germany's borders and filed first applications for asylum. By the end of 2014, Syria had overtaken Afghanistan as the country of origin which produced the largest number of refugees globally. However, the large majority of the over 4 million Syrian refugees fled to Turkey, Jordan, Iraq and Egypt. Turkey accepted 1.59 million refugees from Syria, the highest number, although

3 The study of politicians' perceptions and justifications relates to representations of the actors' belief systems, and there may be a discrepancy between representation and the actual constituents of decision-making processes. It is neither assumed that politicians' representations can always be taken for granted, nor is it proposed that their justifications can never be taken for granted; see, for example, Edelmann (1988) and Spector and Kitsuse (1987). Instead of a priori assumptions about the truth of politicians' representations of their thoughts, an empirical analysis may discover possible discrepancies between justifications and actions which may reflect motives for political action not made explicit by the actors.

4 Contingent refugees receive automatic right of residence for two years and do not enter the asylum procedure. 
Lebanon has the highest proportion (25 percent) of refugees in comparison to the overall population (UNHCR 2016).

As of May 2016, Germany is the EU country with the largest number of asylum applications $(354,038)$ followed by Serbia (and Kosovo) $(313,656)$ and Sweden $(110,579)$, Hungary $(72,505)$ and Austria $(39,786)$ (UNHCR 2016). Germany uses a distribution system of asylum seekers across its federal states, the so-called "Königstein quota system" (Königsteiner Schlüssel) which was developed 60 years ago and takes into account population levels and tax revenues of federal states. North Rhine-Westphalia receives the highest percentage of asylum seekers, followed by Bavaria and Baden-Württemberg (Federal Office for Migration and Refugees 2016).

The refugee crisis had already reached Europe before the civil war started in Syria, and since 2008 refugees have increasingly tried to reach Europe by crossing the Mediterranean Sea. ${ }^{5}$ The German journalist Heribert Prantl, known for his humanitarian voice in the context of migration, describes the humanitarian disaster which unfolded in the Mediterranean in 2011:

The Mediterranean is a mass grave. Since the start of the year, 1,820 people have died in it. They were boat people on their way to Europe, and they died of thirst on the water, drowned in high seas or off Lampedusa, froze out in the cold of Europe's refugee policy. The island of Lampedusa is a life raft in the Mediterranean for those fleeing their homes. Many never reach it; and for those who do, it's not much help. They are sent packing again. Most of the refugees are shipped back immediately to where they came from. (Prantl 2011)

At the beginning of 2015 the EU member states decided to stop the rescue missions in the Mediterranean. The human death toll was seen as collateral to counter the traffickers: "Europe is using dead refugees to shield itself from the others" (Prantl 2015). After outrage from the UNHCR and other organisations, the EU member states agreed to start sending rescue missions into the Mediterranean again (Prantl 2015c). In October 2015, EU president Junker proposed a quota system regarding the distribution of refugees across the EU member states. He did not succeed in implementing the quotas, as the majority of member states rejected the proposal. In March 2016 the European Commission agreed to a deal with Turkey to return all new irregular migrants and asylum seekers from Greece to Turkey, reflecting the EU's aim to secure and militarize its external borders. The deal has been sharply criticised by the UN, the Council of Europe and human rights organizations for violating the right of asylum (ProAsyl 2016).

Public opinion regarding the acceptance of refugees has been changing over the years. In 2013, after the death of over more than 300 refugees near the island of Lampedusa, the majority of Germans were still reluctant to accept additional refugees (43 percent for and 51 percent against additional refugees, ARD Deutschlandtrend 2013 (Spiegel online 2013). However, in July 201554 percent of participants in a public opinion poll supported the acceptance of additional refugees, which increased further to 60 percent in August 2015 (ZDF-Politbarometer 2015). However, by October 2015 the number of supporters of additional refugees had decreased to 45 percent, and only increased slightly in November (47 percent). Voters who supported the CDU/CSU and AfD rejected the acceptance

UNHCR, http://data.unhcr.org/mediterranean/regional.php. 
of additional refugees by 61 percent and 70 percent majorities, respectively. This contrasts with support for additional refugees among 72 percent of Green voters, 54 percent of SPD voters and 48 percent Left Party voters (Spiegel online 2015).

The economic situation in Germany looked good in 2015 and showed a growth factor of 1.7 percent compared to 1.6 percent in the preceding year. ${ }^{6}$ At the end of 2014 unemployment in Germany stood at 6.4 percent; which was relatively low compared to the European Union average, which was 10 percent. $^{7}$

The fact that Angela Merkel, the German Chancellor, had been influential in implementing a policy of severe austerity in Greece, and had been widely criticised for being inhumane, might have been an important factor in the developments regarding asylum policy a year later (see Feldenkirchen, Pfister 2016). It might have also influenced the media and the population to show more empathy towards the refugees arriving in Germany and an understanding that Greece could not cope with the influx of refugees.

Despite the positive response towards the refugees by the mainstream media and political parties in 2015, there was a rise in support of anti-immigration parties such as Alternative für Deutschland (Alternative for Germany; AfD) and the far right. Overall, 2015 saw an increase of crimes motivated by right-wing extremism $(21,933)$ compared to $2014(16,559)$ and $2013(16,557)$. The number of violent crimes directed at foreigners was with 918 , the highest number since the current definition of politically motivated crime was introduced in 2001 (Federal Ministry of the Interior 2015). The number of attacks on refugee shelters increased drastically in 2015. The far right also included an openly racist movement against Muslim residents called "Patriotic Europeans against the Islamisation of the West" (PEGIDA), which organised weekly marches in Dresden and other towns in Germany.

At least 817 attacks on refugee shelters have been carried out since the beginning of this year [2015], according to Germany's Criminal Police Office statistics, which were made public during a parliamentary session on Wednesday. In contrast, there were only 199 similar crimes recorded in 2014. [...] The number of arsons, which amounted to only six in 2014, soared to 65. More than 750 of the 817 attacks were carried out by right-wing extremists, while in 2014 they were responsible for 177 out of $199 .^{8}$

We will see below that politicians from all parties condemned the racist attacks but did not use it to justify a restriction on accepting refugees, as was the case in 1993 when politicians agreed to a constitutional change regarding political asylum.

\section{The party political context}

Since November 2013, Germany has been governed by a coalition government made up of Christian Democrats (CDU; of which Angela Merkel is the party leader), Germany's Social Democrats (SPD) and the CDU's smaller sister party, the Christian Social Union (CSU), which governs in Bavaria only. Die Linke (The Left) party and Bündnis 90/Die

6 http://www.tradingeconomics.com/germany/gdp-growth.

7 http://www.statista.com/statistics/227005/ unemployment-rate-in-germany.

8 https://www.rt.com/news/326187-germany-far-right-attacks-refugees/. 
Grünen (Alliance 90/The Greens) party form the opposition, while the FDP and the AfD are not represented in the Bundestag (lower house). The beginning of 2015 was marked by an increase of asylum seekers arriving at Germany's borders. Up to July 2015 Chancellor Merkel was cautious in her rhetoric on migration and showed reluctance and restriction rather than an open welcome; responding, for example, to a refugee girl from Lebanon who had arrived in Rostock and who was at risk of being deported that Germany "could not manage" if every refugee were to come, (Feldenkirchen, Pfister 2016). This represented the general position of politicians from the CDU, CSU and SPD, who followed a restrictive stance on asylum policy without creating an openly hostile debate on the refugees arriving in Germany. The focus was on developing an EU policy response to the refugee movements into Europe. However, at the annual summer press conference on 31 August, Chancellor Merkel had changed her stance and she used, for the first time, the phrase "we can manage it", which has characterised her policy from then on. She advocated an openly welcoming policy towards refugees, reflected for example in the government's decision in early September to open the border to Hungary so that refugees stranded at the main station in Budapest could travel to Germany (ibid.). The majority of politicians from the CDU and SPD supported her decision, although it involved a suspension of the Dublin Convention. However, politicians from the CSU and especially the head of the CSU, Horst Seehofer, started to openly criticise Chancellor Merkel's decision to explicitly welcome refugees in Germany. This represented a significant shift between the two sister parties; the traditional coalition between the CDU/CSU on migration issues was broken and a new and unusual co-operation between the SPD and the CDU on migration policy occurred. In that sense, the interactive structures between the main political parties have changed significantly since August 2015. There was also a shift in normative structures (reflected for example in political debates) amongst the CDU. Their members emphasised and prioritised humanitarianism and integration rather than the more usual migration rhetoric on overloading and the danger to national stability (see Schneider 2006), as will be outlined further below.

Feldenkirchen and Pfister (2016 online) argue that Merkel was in a strong and powerful position in 2015 to openly welcome refugees and dispense with regulations set out in the Dublin Convention. Merkel has been described throughout her chancellorship as building and consolidating her position of power within the political system, to a significantly greater extent than previous chancellors of Germany: "She had saved for so long and carefully protected her power - now she was intent on spending her political capital" (ibid.). Merkel was supported by a media representation which was welcoming to refugees and a population which showed open support for refugees, as reflected in the large number of volunteers and generally positive public opinion polls (see Prantl 2015b). However, this openness towards refugees was combined with a more restrictive asylum law. In October 2015 an Acceleration Asylum Law was debated and adopted, which declared Albania, Kosovo and Montenegro as safe countries of origin. ${ }^{9}$ It further aimed at accelerating the repatriation of rejected asylum seekers and included restrictions on financial support whereby asylum seekers waiting in reception centres receive payments in kind "as far as possible" and rejected asylum seekers are stripped of their social benefits. The law was criticised by organisations which advocate refugee rights such as ProAsyl for being inhumane and vio-

9 The existing safe countries of origin include all EU member states, Norway, Switzerland, Ghana, Senegal, Bosnia-Herzegovina, Macedonia and Serbia. 
lating the constitutional article on human dignity..$^{10}$ Apart from restrictive measures, the law introduced German language and "living in Germany" courses in order to enhance the integration of recognized refugees. I will come back to this law when I discuss politicians' decision-making processes below.

Applying Archer's model of structural elaboration, the above scenario shows that the political structures at the beginning of 2015 were marked by a loose co-operation between the CDU, CSU and SPD, representing an implicit rather than explicit stance on asylum policy which reflected a mix between restriction and a reluctant welcome. Due to the fact that the normative structures within the party political system had not developed an explicitly restrictive position on asylum policy, Merkel was able to shift to an explicitly welcoming policy at the beginning of September 2016, supported by the majority of CDU and SPD politicians. However, her powerful position and the support of the media and the wider population were important factors in her shift in asylum policy. Overall, the political debate developed from one which implicitly represented a mix of restriction and reluctant welcome to one which was explicitly welcoming, although the asylum law which was agreed upon in October 2015 underscored the fact that the "welcome" and humanitarian gesture was not open to all. Countries such as Albania, Kosovo and Montenegro were declared safe countries of origin, and strict financial and welfare cuts were implemented for asylum-seekers whose applications were unsuccessful or viewed as being potentially unsuccessful.

\section{Politicians' justification systems}

This section will look at politicians' justification systems in more depth. It is informed, in particular, by an analysis of a political debate which took place in the Bundestag on 15 October 2015. The debate related to the intake of refugees in general and, in particular, to the new asylum law discussed above (Drucksache 18/6386). The law was adopted with 475 members of the Bundestag voting in favour, 68 voting against and 57 abstaining. The analysis applied Strauss and Corbin's (1998) open coding strategy to identify themes and sub-themes which politicians represented in their decision to vote for or against the new asylum procedure/law. NVivo software was used to analyse the debate. 23 politicians contributed to the debate with seven contributions from the CDU, six from SPD, four contributions from Bündnis 90/Die Grünen, four from Die Linke Party and two contributions from the CSU. Below I present the themes that were used to justify the politicians' decisions and analyse to what extent politicians from different political parties used similar/ dissimilar justifications.

The meta-themes which were identified in the debate included politicians' perceptions and goals with regard to domestic policy, asylum policy, foreign policy, European policy and the global situation. Another major theme related to individuals' value systems. CSU politicians who countered a policy of welcome stressed the aspect of the burden on society, referring to themes such as overloading, risk of national instability, limits of acceptance and crime rates amongst refugees. Their other emphasis was on social and cultural integration of refugees. These themes were combined with a strong support for the new asylum law,

10 https://www.proasyl.de. 
some references to European border controls and a distinction between needy and nonneedy applicants. CDU politicians placed less emphasis on the burden on society and national stability and focused more on the social welfare of refugees (especially children and young people) and the values of the constitution and the pragmatism reflected in Merkel's phrase "we can manage it". Racism was condemned and empathy towards refugees advocated, while also acknowledging that there is anxiety among some parts of the population which had to be responded to. The distinction between needy and non-needy migrants was highlighted and, similar to the CSU, strong support for the new asylum law (and especially support for safe countries of origin and the refoulement of unsuccessful applicants) was proclaimed. The SPD emphasised that more financial support was needed for municipalities which experienced a rise in refugees. Similar to the CDU and CSU, SPD politicians focused on the social integration of refugees, European solidarity, support for the new asylum law (although the use of vouchers was criticised) and a distinction between socalled needy and non-needy migrants. ${ }^{11}$ They mentioned the worries of some people in the population, criticised racism and supported help for the regions from which refugees were arriving. Die Grünen/Bündnis 90 and Die Linke covered similar topics, mainly criticising the proposal to reduce the financial support for rejected refugees or refugees arriving from safe countries of origin, the safe country of origin rule in general and the co-operation with Turkey. They highlighted constitutional values, criticised racism and said that the causes of refugee movements need to be tackled and the arms trade stopped. Overall, the majority of politicians focused on the advocating of humanitarianism within and outside Germany, although this contrasted with their support for a law which introduced restrictive measures for refugees arriving from so-called safe countries of origin, which was seen by refugee organisations as violating humanitarianism.

\section{DISCUSSION AND CONCLUSION}

The following brings together the above sections, highlighting how factors at the agency level and the structural level and the connection or (lack of connection) between them influenced migration admission policy in Germany in 2015. The social, economic and political environment in 2015 was characterised by rising migration numbers, a strong economy, a very visible and audible "refugees welcome" movement but also a rise in xenophobic violence. The party political system was characterised in the first months of 2015 by the traditional co-operation between the CDU and CSU, reflecting a passive restrictive stance on asylum policy. By September 2015 this had changed into an openly welcoming position towards refugees who did not arrive from safe countries of origin by Chancellor Merkel. A new strategic alliance emerged between the CDU and SPD, and a conflict over migration arose between the CDU and CSU, suspending the traditional alliance between the CDU and CSU on the issue of migration. At the politicians' decision making level, themes of humanitarianism within Germany and refugee integration were dominant among CDU and SPD politicians, while the CSU emphasised the burden on society and the risk to national stability.

11 Interestingly the term 'bogus asylum-seekers' (Scheinasylant) which was dominant in the 1993 debate was not used by any of the politicians; instead, migrants were classified by neediness of protection. 
How are these different dimensions and developments regarding the wider environment, the political party system and politicians' decision-making connected? This article has argued that immigration policy is influenced by both structural and agency factors and processes which occur between the two. Macro factors such as the economy and the socio-political environment and party political structures are therefore not sufficient to explain developments in immigration policy and need to be analysed in the context of agency. I draw attention to Freeman's (1979) earlier approach which offered a flexible framework for the study of immigration policy, which acknowledged the wider socio-economic and narrower party political structures but also emphasised the mediating role of politicians who interpret and maintain or change these structures. Figure 1 showed how politicians are interconnected with the wider environment and the party political system through their agency; on the one hand their agency elaborates structures in the party political context and the wider environment and on the other hand their agency is limited or enhanced by these structures. ${ }^{12}$

The article shows that the wider environment in 2015 was characterised by increasing asylum applications, an increasing support by the general public and the media regarding the acceptance of refugees, a rise in anti-immigration parties, a positive economic situation and a European policy which focused on the control of its external borders. Although migration numbers were mentioned by politicians, they were not a dominant theme in the debate relating to a new asylum law; only the CSU emphasised numbers and overloading. The positive economic situation was not highlighted in the debate explicitly although it was reflected indirectly in the phrase "we can manage it". The ascent of the far right, a major development during 2015, was highlighted in the debate and criticised; however, it was not connected to the theme of national instability or used to argue for a restrictive admission policy towards asylum-seekers, as had happened in the debate surrounding the constitutional change regarding political asylum in 1993. Instead, more focus was placed on the welcoming attitude towards refugees by the general public. Europe was reflected in the debate and many goals were directed at a European level (e.g. EU burden-sharing, solidarity, EU asylum policy). However, the major themes in the debate focused on normative principles (in particular, the perception and advocating of humanitarianism within Germany) and the goal of refugee integration rather than referring to processes in the wider environment. This contrasts clearly with 1993 when the (temporary) rise of in numbers of asylum seekers (caused by the civil war in former Yugoslavia) and the ascent of the far right (influenced by the emphasis on ethnic nationalism triggered by German reunification), were linked to the theme of national instability in order to justify the constitutional change and to implement a more restrictive asylum legislation (see Schneider 2006).

The article also notes how politicians changed the interactive and normative structures within the party political system whereby the usual alliance between the two conservative parties (CDU and CSU) weakened and instead the CDU's position on asylum policy became more aligned with that of the Social Democrats (SPD). In their discourse, CDU and SPD politicians advocated an explicit humanitarianism within Germany and emphasised the integration and welcome of refugees. However, they also supported (together with the $\mathrm{CSU})$ more restrictive asylum procedures, which proposed a distinction between needy

12 Agency is here understood through its psycho-social dimension (e.g. individuals' beliefs, perceptions and goals) and action itself. 
and non-needy refugees and migrants. In this way they limited their humanitarianism to specific groups of migrants. While this article is going to press, the situation described in this article is changing, and more restrictive rhetoric regarding refugees and asylum seekers is (again) dominating the political and the public debate.

\section{REFERENCES}

Archer, Margaret S. (1995). Realist Social Theory - The Morphogenic Approach. Cambridge University Press.

Boswell, Christina (2009). The Political Uses of Expert Knowledge: Immigration Policy and Social Research. Cambridge: Cambridge University Press.

Bundesamt für Migration und Flüchtlinge (2016). Das Bundesamt in Zahlen 2015 - Asyl., http://www.bamf.de/SharedDocs/Anlagen/DE/Publikationen/Broschueren/bundesamt-in zahlen-2015-asyl.pdf (26. 6. 2016).

Castles, Stephen (2007). Twenty-First-Century Migration as a Challenge to Sociology. Journal of Ethnic and Migration Studies 33/3, 351-371.

Castles, Stephen, Kosack, Godula (1973). Immigrant Workers and Class Structure in Western Europe. Oxford: Oxford University Press.

Cornelius, Wayne A., Rosenblum, Marc R. (2005). Immigration and Politics. Annual Review of Political Science 8, 99-119.

Edelmann, Murray (1988). Constructing the Political Spectacle. Chicago: University of Chicago Press.

Federal Ministry of the Interior (2015). Annual Report on the Protection of the Constitution: Facts and Trends, https://www.verfassungsschutz.de/embed/annual-report-2015-summary.pdf (25. 5. 2016).

Federal Office for Migration and Refugees (2016). The distribution of asylum applicants, http://www.bamf.de/EN/Migration/AsylFluechtlinge/Asylverfahren/Verteilung/ verteilung-node.html.

Feldenkirchen, Markus, Pfister, René (2016). The Isolated Chancellor: What Is Driving Angela Merkel? Spiegel online, January 25, (25. 5. 2016).

Freeman, Gary. P. (1979). Immigrant Labor and Racial Conflict in Industrial Societies. Princeton: Princeton University Press.

Freeman, Gary P. (1995). Modes of Immigration Politics in Liberal Democratic States, International Migration Review 29/4, 881-902.

Freeman, Gary P. (2006) National Models, Policy Types, and the Politics of Immigration in Liberal Democracies. West European Politics 29/2, 227-247.

Geddes, Andrew P. (2003) The Politics of Migration and Immigration in Europe. London: Sage. Gibney, Matthew (2004). Ethics of Political Asylum. Cambridge: Cambridge University Press. Guiraudon, Virginie (2000). European Integration and Migration Policy: Vertical Policy-Making as Venue Shopping. Journal of Common Market Studies 38/2, 251-271.

Joppke, Christian (1999). Immigration and the Nation-State: The United States, Germany, and Great Britain. Oxford: Oxford University Press.

Joppke, Christian (2008). Immigration and the Identity of Citizenship: The Paradox of Universalism. Citizenship Studies 12/6, 533-546.

Kay, Diane, Miles, Robert (1992). Refugees or Migrant Workers? London: Routledge. 
Lahav, Gallya, Guiraudon, Virginie (2006). Immigration Policy in Europe: The Politics of Control. West European Politics, Special Issue 29/2, 201-223.

Lahav, Gallya, Guiraudon, Virginie (2006). Actors and Venues in Immigration Control: Closing the Gap Between Political Demands and Policy Outcomes. West European Politics 29/2, 201-223.

Levine, Paul (1999). The Welfare Economics of Immigration Control. Journal of Population Economics 12/1, 23-43.

Kelly, Ninette, Trebilcock, Michael (1998). The Making of a Mosaic: A History of Canadian Immigration Policy. Toronto: University of Toronto Press.

Münch, Ursula (1992). Asylpolitik in der Bundesrepublik Deutschland. Opladen: Leske + Budrich.

Perlmutter, Ted (1996). Bringing Parties Back In. International Migration Review 30/1, 375-388.

Prantl, Heribert (2011). Asylum in Europe - a mirage across the water. Süddeutsche Zeitung, 3. 8. 2016.

Prantl, Heribert (2015a). How the EU is killing refugees. Süddeutsche Zeitung.

Prantl, Heribert (2015b). Viewpoint: Munich migrant welcome shames Europe. Süddeutsche Zeitung, 7. 9. 2015.

Prantl, Heribert (2015c). Im Namen der Menschlichkeit Rettet die Flüchtlinge! Berlin: Ullstein Buchverlage.

ProAsyl (2016). Despite subsequent improvements: EU-Turkey deal violates fundamental human rights! Frankfurt am Main: ProAsyl, 17. 3. 2016.

Rich, Paul (1986). Race and Empire in British Politics. Cambridge: Cambridge University Press.

Rottman, Andy J. et al. (2009). The Path to Asylum in the US and the Determinants for Who Gets in and Why. The International Migration Review 43/1, 3-34.

Sassen, Saskia (1996). Losing Control? Sovereignty in an Age of Globalization. New York: Columbia University Press.

Schain, Martin A. (2006). The Extreme Right and Immigration Policy-Making: Measuring Direct and Indirect Effects. West European Politics 29/2, 270-289.

Schneider, Claudia (2006). Analysing immigration control policy: A case study regarding the amendment of Art. 16 (2) of the German Constitution (Doctoral dissertation, London School of Economics and Political Science, University of London), http://ethos.bl.uk/ OrderDetails.do?uin=uk.bl.ethos.439537.

Schneider Claudia (2009). The use of conceptual frameworks to investigate the structureagency link in comparative immigration policy and its relevance to social work. Theories and Methods in Social Work: International Perspectives (ed. Vesna Leskošek). Ljubljana: University of Ljubljana, Faculty of Social Work.

Sen, Amartya (1982). Choice, Welfare and Measurement. Oxford: Blackwell.

Simon, Herbert (1982). Models of Bounded Rationality. Cambridge, MA: MIT Press.

Spector, Malcolm, Kitsuse, John I. (1987). Constructing Social Problems. New York: Aldine de Gruyter.

Spiegel online (2015). Mehrheit gegen zusaetzliche Fluechtlinge in Deutschland, http:// www.spiegel.de/politik/deutschland/mehrheit-gegen-zusaetzlichen-fluechtlinge-in-deutschland-a-927256.html (16. 7. 2016). 
Statham, Paul, Geddes, Andrew (2006). Elites and the "Organised Public": Who Drives British Immigration Politics and in which Direction? West European Politics 29/2, 248-269.

Strauss, Anselm, Corbin, Juliet (1998). Basics of Qualitative Research. Thousand Oaks, CA: Sage.

Thouez, Colleen, Channac, Frédérique (2006). Shaping International Migration Policy: The Role of Regional Consultative Processes. West European Politics 29/2, 370-387.

UNHCR (2016a). EUROPE: Syrian Asylum Applications - From April 2011 to May 2016, https://data.unhcr.org/syrianrefugees/asylum.php (16. 7. 2016).

UNHCR (2016b). Key Facts and Figures, http://ww2.unhcr.org.uk/about-us/key-facts-andfigures.html (16. 7. 2016).

Verfassungsschutz (2014). Figures and Facts Right Wing Extremism, https://www.verfassungsschutz.de/en/fields-of-work/right-wing-extremism/figures-and-facts-rightwing-extremism/right-wing-extremist-crimes-and-violent-offences-2014.html.

ZDF-Politbarometer (2015), https://presseportal.zdf.de/.

Zincone, Giovanna (2006). The Making of Policies: Immigration and Immigrants in Italy. Journal of Ethnic and Migration Studies 32/3, 347-375. 


\section{POVZETEK}

\section{KONCEPTUALNI OKVIR ANALIZE POLITIK SPREJEMA: ŠTUDIJA PRIMERA TRENUTNE USMERITVE NEMŠKE AZILNE POLITIKE \\ Claudia SCHNEIDER}

Nemška azilna politika je leta 2015, ko se je v primerjavi s prejšnjimi leti občutno povečalo število prošenj za odobritev azila, doživela presenetljiv premik. V nasprotju s pričakovanji nemška vlada ni zaostrila pogojev sprejema, kot je bilo to v navadi v preteklosti, temveč je beguncem izrazila dobrodošlico. Članek ponuja analizo dogodkov, ki so pripeljali do tovrstne vladne usmeritve, in pri tem uporabi konceptualni okvir, ki upošteva strukturo, delovanje in njun preplet. Osredotoča se na procese znotraj strankarskega političnega sistema in analizo morebitnega vpliva nanj s strani struktur v širšem družbenopolitičnem in ekonomskem okolju, ter percepcij, verovanj in ciljev politikov. Poudarja dejstvo, da na politike sprejema vplivajo strukturni dejavniki, delovanje posameznikov in procesi, ki nastanejo ob njunem prepletu. V tem smislu članek gradi predvsem na Freemanovem pristopu (1979), ki ponuja fleksibilen okvir za preučevanje politik ob upoštevanju širših socialnoekonomskih in strankarskih struktur, ter mediacijski vlogi politikov, ki te strukture bodisi ohranjajo ali spreminjajo. Izsledki kažejo, da so se leta 2015 politiki v Nemčiji za upravičevanje svoje pozicioniranosti v odnosu do azilne politike raje sklicevali na vrednote kot na dejavnike $\mathrm{v}$ družbenopolitičnem okolju. Ta dinamika je v nasprotju $\mathrm{z}$ dinamiko spreminjanja nemške azilne politike leta 1993, ko so dogodki v širšem okolju sprožili javne debate, nastrojene proti priseljevanju in bili uporabljeni oz. zlorabljeni za dosego spremembe člena zakona o azilu (glej Schneider 2006). Članek osvetljuje tudi spreminjanje struktur znotraj strankarskega političnega sistema, ko je kanclerka Merklova naznanila zavezanost za beguncem prijazno azilno politiko. Posledično so se obstoječe navezave med dvema konzervativnima strankama (CDU in CSU) prekinile, stališča stranke CSU pa so se zbližala s socialnimi demokrati (SPD). Politiki CDU in SPD so začeli zagovarjati eksplicitni humanitarizem in poudarjati pomen integracije beguncev. Prav tako pa so (skupaj s CSU) podprli bolj restriktivne postopke podeljevanja azila, ki bi ločevali med bolj in manj zaščite potrebnimi migranti in begunci in tako omejili domet humanitarizma v Nemčiji na specifične skupine migrantov in beguncev. Restriktivna retorika o beguncih in prosilcih se tako nadaljuje in $\mathrm{v}$ političnih debatah (ponovno) začenja prevladovati. 